\title{
EXTRA VIRGIN OLIVE OIL EFFECT IN THE COMBINATION OF ALCOHOL AND BENZENE ON THE KIDNEY OF RATTUS NOVERGICUS
}

\section{ADETUNJI OPEYEMI ADEBOLA ${ }^{1 *}$, ADETUNJI OLUWASEYI ADEGOKE², NWOBI JOSEPH CHIGBOGU ${ }^{2}$, ADETUNJI IYABODE TOYIN ${ }^{3}$, OGUNBIYI BABAFEMI TOSIN ${ }^{2}$, NWOBI NNENNA LINDA ${ }^{4}$}

\begin{abstract}
${ }^{1}$ Department of Anatomy, School of Basic Medical Sciences, Benjamin S. Carson (Snr.) College of Health and Medical Sciences, Babcock University, Ogun State, Nigeria. ${ }^{2}$ Department of Biochemistry, School of Basic Medical Sciences, Benjamin S. Carson (Snr)) College of Health and Medical Sciences, Babcock University, Ogun State, Nigeria. ${ }^{3}$ Department of Microbiology, Federal University of Agriculture, Abeokuta, Ogun State, Nigeria. ${ }^{4}$ Department of Chemical Pathology, School of Basic Clinical Sciences, Benjamin S. Carson (Snr.) College of Health and Medical Sciences, Babcock University, Ogun State, Nigeria. Email: adetunjiop@babcock.edu.ng/addturng1809@gmail.com
\end{abstract}

Received: 01 September 2021, Revised and Accepted: 12 September 2021

\section{ABSTRACT}

Objective: This study investigated the use of extra virgin olive oil (EVOO), which is said to possess anti-inflammatory components as an ameliorative substance for the induced inflammation.

Methods: Forty-eight female Wistar rats were used for this study. They were divided into eight (1-8) groups (n=6); Control, Ethanol, Benzene, E+B, $\mathrm{E}+\mathrm{O}, \mathrm{B}+\mathrm{O}, \mathrm{E}+\mathrm{B}+\mathrm{O}$ with the administration of $25 \%$ Ethanol, $200 \mathrm{mg} / \mathrm{kg} / \mathrm{b} . \mathrm{w}$ Benzene, $2 \mathrm{ml}(\mathrm{O})$ EVOO in respect to the tagged grouping names. Animals were euthanized through cervical dislocation after the last day of administration and the liver was excised and part was fixed in formalin solution of $10 \%$ for histological processing and the other part was homogenized for biochemical assay in phosphate buffer before centrifugation.

Results: Histological evidence creates an understanding of the nephrons in which benzene and ethanol manifest likewise the mitigated ability of EVOO. The relative organ weight provides information on the extent of the damage on nephrons. The kidney test level is significantly expressed.

Conclusion: Ethanol and benzene in combination cause serious damage; also, they separately induce nephrons dysfunction. EVOO was shown to mitigate these nephrons damages.

Keywords: Ethanol, Benzene, Extra virgin olive oil, Nephron.

(C) 2021 The Authors. Published by Innovare Academic Sciences Pvt Ltd. This is an open access article under the CC BY license (http://creativecommons org/licenses/by/4.0/) DOI: http://dx.doi.org/10.22159/ijms.2021v9i6.43029 Journal homepage: https://innovareacademics.in/journals/index.php/ijms

\section{INTRODUCTION}

Damaged cells and toxic compounds are factors that induce acute and/ or chronic inflammatory responses in the heart, pancreas, liver, kidney, lung, brain, intestinal tract, and reproductive system, potentially leading to tissue damage or disease [1]. At the tissue level, inflammation is characterized by redness, swelling, heat, pain, and loss of tissue function, which result from local immune, vascular and inflammatory cell responses to infection or injury [2]. Drugs can cause damage to the kidney and people with underlying kidney conditions may not be able to take NSAID medications, not even in low doses for a short time [3]

Nephrotoxicity and hepatotoxicity have been reported following human and animal exposure to unleaded petrol [4]. Kareem Saeed showed that chronic ethanol administration in rodents has been demonstrated to induce a number of hepatic changes, including hepatocellular necrosis, inflammatory cell infiltration, terminal hepatic venular sclerosis, and tumor development [5] and histologically evidence by Adetunji led us to understand that cellular hepatic degeneration occurs in benzene and ethanol-induced in rats model [6]. During acute inflammatory responses, cellular and molecular events and interactions efficiently minimize impending injury or infection. This mitigation process contributes to the restoration of tissue homeostasis and resolution of acute inflammation. Uncontrolled acute inflammation may become chronic, contributing to a variety of chronic inflammatory diseases [7].

Benzene occurs naturally as a product of pyrolysis, mostly through anthropogenic sources as a clear, colorless liquid with a sweet odor, highly volatile, and flammable liquid with poor water solubility [8] Inhalation exposures predominate and oral exposure to benzene occurs through ingestion of contaminated food and drinking water though inhalation is the primary route of exposure to benzene [9]. Multiple functional abnormalities of renal tubules may be associated with ethanol-induced changes in membrane composition and lipid peroxidation [10]. Extra virgin olive oil (EVOO) is a liquid obtained from olives and a naturally occurring phenolic secoiridoid which has a potential nutraceutical therapeutic for inflammation, neurodegenerative diseases, and many malignancies, especially breast cancer and hepatic degeneration $[6,11,12]$.

\section{METHODS}

Preparation of reagent and procurement

Ethanol (75\%) was gotten from the Department of Anatomy Babcock University, Ilishan Remo, Ogun state. Benzene was gotten from the Department of Anatomy, University of Ibadan, Ibadan, Oyo state. Extravirgin olive oil was purchased from Jumia online-store Lagos, Nigeria. Preparation for the experiment was done out of the procured reagent as follow: Ethanol (25\%) was obtained by measuring $10 \mathrm{ml}$ of the $75 \%$ ethanol with an addition of $20 \mathrm{mls}$ of distilled water measured using a measuring cylinder.

\section{Animal housing, treatment and grouping}

Research approval was gotten from the Babcock University Research Ethical Committee following all rules and regulations guiding animal research and teaching (BUHREC: 799/19). Forty-eight adult Wistar rats (120 g) were gotten and housed in Babcock University animal housing facility Ilishan-Remo, Ogun State. They were placed in plastic cages with net covers for ventilation. Distilled water and pelletized food were given to the Wistar rats daily. Wood shavings were used as beddings for the 
Wistar rats. The beddings were changed every 2 days to avoid build-up of toxic ammonia levels. The 48 Wistar rats were acclimatized for 7 days and were divided into 8 groups of six animals per group. Table 1 followed the administration; ethanol was administered at $2 \mathrm{mls}$ to the rats in Ethanol, $\mathrm{E}+\mathrm{B}, \mathrm{E}+\mathrm{O}$ and $\mathrm{E}+\mathrm{B}+\mathrm{O}$ orally individually or in combination, respectively, twice and Benzene was administered at $200 \mathrm{mg} / \mathrm{kg}$ to the rats in Benzene, $\mathrm{E}+\mathrm{B}, \mathrm{B}+\mathrm{O}$ and $\mathrm{E}+\mathrm{B}+\mathrm{O}$ orally individually or in combination, respectively, twice a week while EVOO was administered at $2 \mathrm{ml}$ to the rats in group $\mathrm{E}+\mathrm{O}, \mathrm{B}+\mathrm{O}, \mathrm{E}+\mathrm{B}+\mathrm{O}$ and EVOO orally individually or in combination respectively twice a week. Also, a number of deaths were recorded during the course of the experiment.

\section{Measurement of body weight and organ weight}

The body weight of the rats were measured twice a week throughout the duration of the study with the use of a measuring balance, this was done in order to check the weight gain or loss in various animals of each group.

\section{Animal sacrifice}

Following the 4 weeks added experiment, the rats was fasted overnight and euthanized under ketamine anesthesia $(100 \mathrm{mg} / \mathrm{kg})$. The kidneys were carefully excised through abdominal incision using scalpel and forceps. Blood was collected from the left ventricle with $2 \mathrm{ml}$ syringe and then stored in a sample bottle so as to carry out Urea and Creatinine tests.The excised kidneys were kept in a sample bottle filled with $10 \%$ formal-saline solution for histological analysis.

\section{Histological techniques}

The kidneys were excised and were fixed in $10 \%$ formal-saline and were processed using the routine tissue processing protocols and the tissue slides was prepared using Hematoxylin and Eosin (H\&E) for general histological appearance and Periodic Acid Schiff (PAS) for visualizing connective tissue especially collagen in tissue sections $[13,14]$.

\section{Statistical analysis}

All the results were represented as a grouped data and analyzed using the Graphpad Prism 8.0 software using one-way analysis of variance. The results were expressed as Mean \pm SEM. Newman-Keuls post hoc test was used to compare the means.

\section{RESULTS}

According to Figs. 1 and 2 a significant reduction $(p<0.05)$ was observed in the experimental subject is compared with both the positive and negative control.

\section{DISCUSSION}

Ethanol and Benzene were substances used in this experiment as they are common substances the society and most scientists are exposed to. As much as protection is highly recommended when these substances are being used, it is necessary to know the possible ameliorative methods for the treatment of exposed individuals. EVOO can be used in cooking for consumption as shown earlier stated in the Mediterranean

Table 1: Grouping of experimental rats

\begin{tabular}{|c|c|c|}
\hline Group & $\begin{array}{l}\text { Number of } \\
\text { animals }\end{array}$ & Treatment schedule \\
\hline 1 & 6 & A placebo of water (Control) \\
\hline 2 & 6 & $25 \%$ ethanol (E) $2 \mathrm{ml} / \mathrm{kg} . \mathrm{bw}$ twice a week \\
\hline 3 & 6 & Benzene (B) at $200 \mathrm{mg} / \mathrm{kg} . \mathrm{bw}$, twice a week \\
\hline 4 & 6 & $25 \%$ ethanol + benzene $(\mathrm{E}+\mathrm{B})$ twice in a week \\
\hline 5 & 6 & $\begin{array}{l}25 \% \text { ethanol + extra-virgin olive oil }(E+0) \\
\text { twice a week }\end{array}$ \\
\hline 6 & 6 & $\begin{array}{l}\text { Benzene + extra-virgin olive oil }(B+0) \text { twice a } \\
\text { week }\end{array}$ \\
\hline 7 & 6 & $\begin{array}{l}25 \% \text { ethanol + benzene }+ \text { extra-virgin olive oil } \\
(\mathrm{E}+\mathrm{B}+\mathrm{O}) \text { twice in a week }\end{array}$ \\
\hline 8 & 6 & Extra-virgin olive oil at $2 \mathrm{ml} / \mathrm{kg} . b w$ per day \\
\hline
\end{tabular}

diet but it is not known to all that this oil contains anti-inflammatory properties. The histological analysis and function tests carried out in this experiment clearly show the inflammatory effects of ethanol and

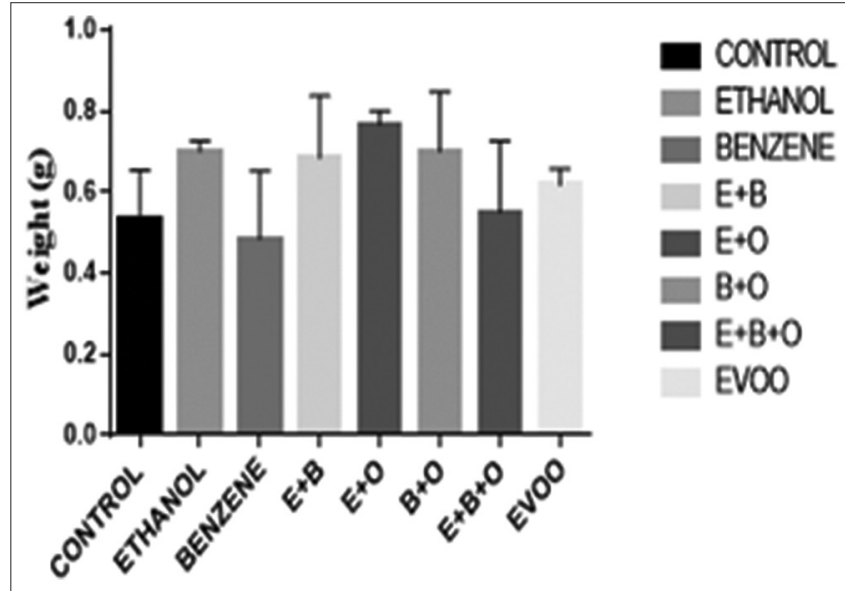

Fig. 1: Bar graph showing the relative organ weight in the control, ethanol, Benzene, $\mathrm{E}+\mathrm{B}=$ Ethanol + Benzene, $\mathrm{E}+\mathrm{O}=$ Ethanol + Extra Virgin Olive Oil, B+O= Benzene + Extra Virgin Olive Oil, E+B+O= Ethanol + Benzene + Extra Virgin Olive Oil, EVOO= Extra Virgin Olive Oil

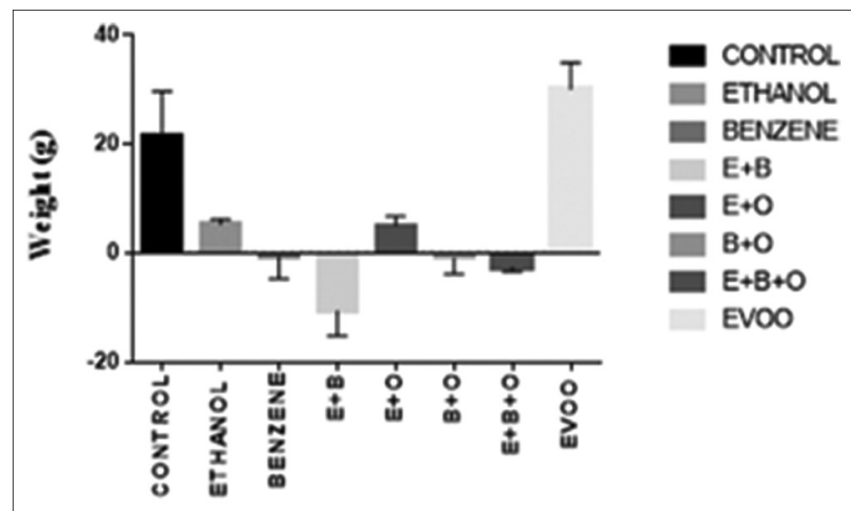

Fig. 2: Bar graph showing the body weight difference in the control, ethanol, benzene, $\mathrm{E}+\mathrm{B}=\mathrm{Ethanol}+\mathrm{Benzene}, \mathrm{E}+\mathrm{O}=\mathrm{Ethanol}$ + Extra Virgin Olive Oil, B+O= Benzene + Extra Virgin Olive Oil, $\mathrm{E}+\mathrm{B}+\mathrm{O}=$ Ethanol + Benzene + Extra Virgin Olive Oil, EV00 = Extra Virgin Olive Oil

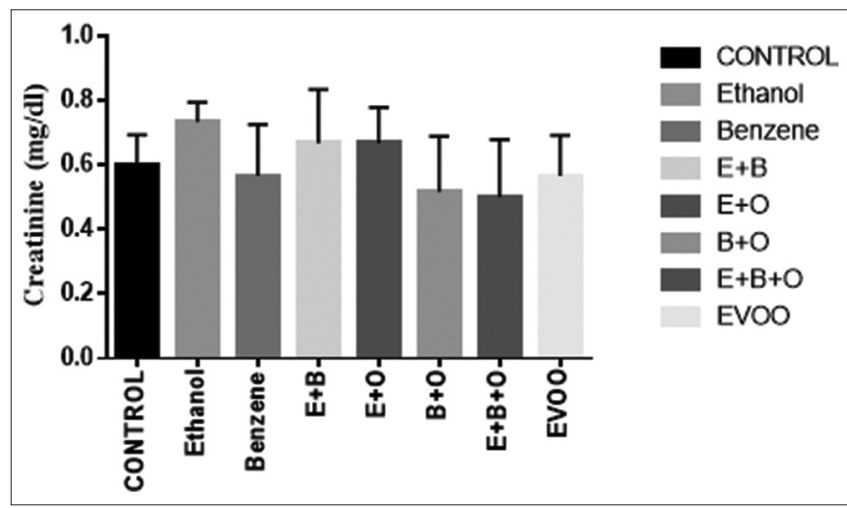

Fig. 3: Bar graph showing the creatinine in the control, ethanol, benzene, $\mathrm{E}+\mathrm{B}=\mathrm{Ethanol}+\mathrm{Benzene}, \mathrm{E}+\mathrm{O}=\mathrm{Ethanol}+$ Extra Virgin Olive Oil, $\mathrm{B}+\mathrm{O}=$ Benzene + Extra Virgin Olive Oil, $\mathrm{E}+\mathrm{B}+\mathrm{O}=$ Ethanol + Benzene + Extra Virgin Olive Oil, EV00= Extra Virgin Olive Oil 
benzene on the kidney when ingested. The presence of fibrosis is a clear indication.

\section{Physical and morphological analysis}

The mean weight of all groups was compared to themselves at the two intervals of initial and final. The mean weights of Ethanol, Benzene, $\mathrm{B}+\mathrm{E}, \mathrm{E}+\mathrm{O}, \mathrm{B}+\mathrm{O}$, and $\mathrm{B}+\mathrm{E}+\mathrm{O}$ groups, showed a significant decrease when compared to the control group. The mean weights of Ethanol, Benzene

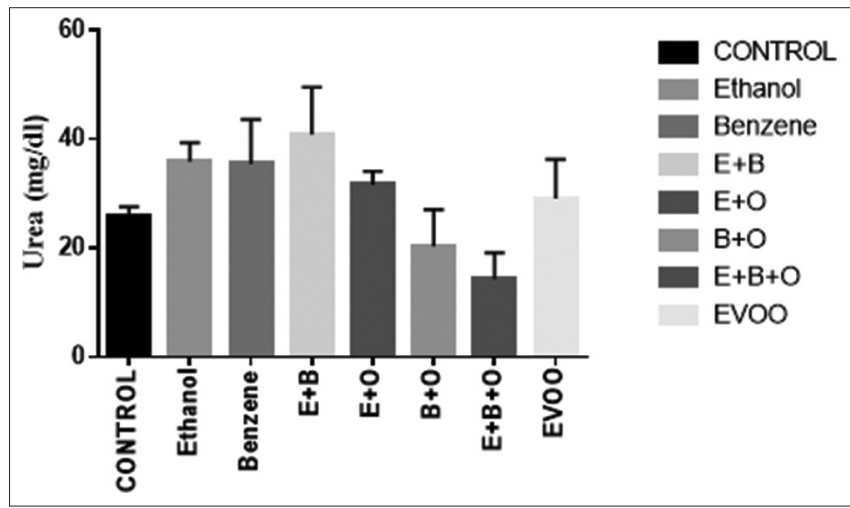

Fig. 4: Bar graph showing the urea test in the control, ethanol, benzene, $\mathrm{E}+\mathrm{B}=$ Ethanol + Benzene, $\mathrm{E}+\mathrm{O}=$ Ethanol + Extra Virgin Olive Oil, $\mathrm{B}+\mathbf{0}=$ Benzene + Extra Virgin Olive Oil, $\mathrm{E}+\mathrm{B}+\mathbf{0}=$ Ethanol + Benzene + Extra Virgin Olive Oil, EVO0= Extra Virgin Olive Oil
$\mathrm{B}+\mathrm{E}, \mathrm{E}+\mathrm{O}, \mathrm{B}+\mathrm{O}$, and $\mathrm{B}+\mathrm{E}+\mathrm{O}$, respectively, also showed a significant decrease when compared to EVOO.

When the bodyweight difference of all groups was compared to themselves, the bodyweight difference of Ethanol, Benzene, $\mathrm{B}+\mathrm{E}, \mathrm{E}+\mathrm{O}$, $\mathrm{B}+\mathrm{O}$, and $\mathrm{B}+\mathrm{E}+\mathrm{O}$ groups, showed a significant decrease when compared to control group. The body weight difference of Ethanol, Benzene, $\mathrm{B}+\mathrm{E}$, $\mathrm{E}+\mathrm{O}, \mathrm{B}+\mathrm{O}$, and $\mathrm{B}+\mathrm{E}+\mathrm{O}$ groups, also showed a significant decrease when compared to the EVOO group.

When the organ weight of all groups was compared to themselves, the organ weight of Ethanol, Benzene, $\mathrm{B}+\mathrm{E}, \mathrm{E}+\mathrm{O}, \mathrm{B}+\mathrm{O}$, and $\mathrm{B}+\mathrm{E}+\mathrm{O}$ groups, showed a significant decrease when compared to control group. The body weight difference of Ethanol, Benzene, $\mathrm{B}+\mathrm{E}, \mathrm{E}+\mathrm{O}, \mathrm{B}+\mathrm{O}$, and $\mathrm{B}+\mathrm{E}+\mathrm{O}$ groups, showed a significant decrease when compared to EVOO only group.

When the relative organ weight of all groups was compared to themselves, the relative organ weight of Control, Ethanol, Benzene, Benzene+Ethanol, Ethanol+EVOO, Benzene+EVOO, and Benzene+Ethanol+EVOO groups, showed a slight decrease when compared to EVOO group. When compared to control group the relative organ weight of Ethanol+EVOO was slightly lesser. Also when compared to Ethanol+EVOO the relative organ weight of Benzene+EVOO was slightly higher.

\section{Biochemical analysis}

Creatinine test and urea test (Figs. 3 and 4) shows the progression of damage in Ethanol, Benzene, and E+B groups and ameliorative effect

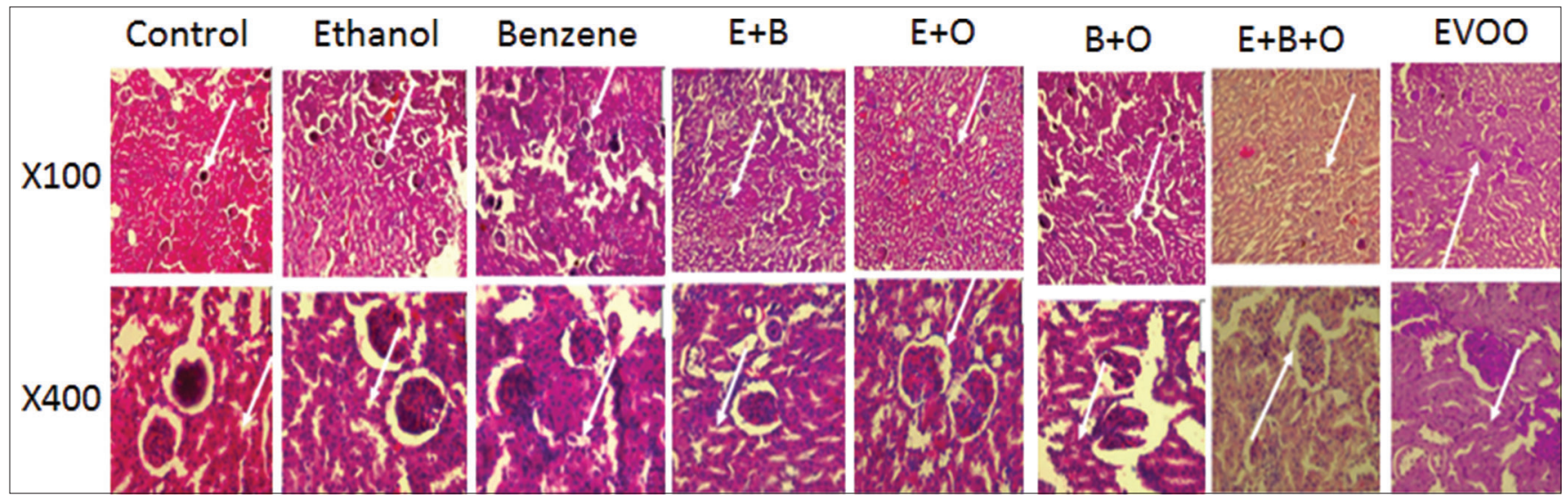

Fig. 5: Section showing renal tissue consisting of glomerulus, proximal tubule and distal tubule of control, ethanol, benzene, $E+B=E$ Ethanol + Benzene, E+O= Ethanol + Extra Virgin Olive Oil, B+O=Benzene + Extra Virgin Olive Oil, E+B+0=Ethanol + Benzene + Extra Virgin Olive Oil, EVOO=Extra Virgin Olive Oil $(\mathrm{H} \& \mathrm{E}: \times 100$ and $\times 400)$

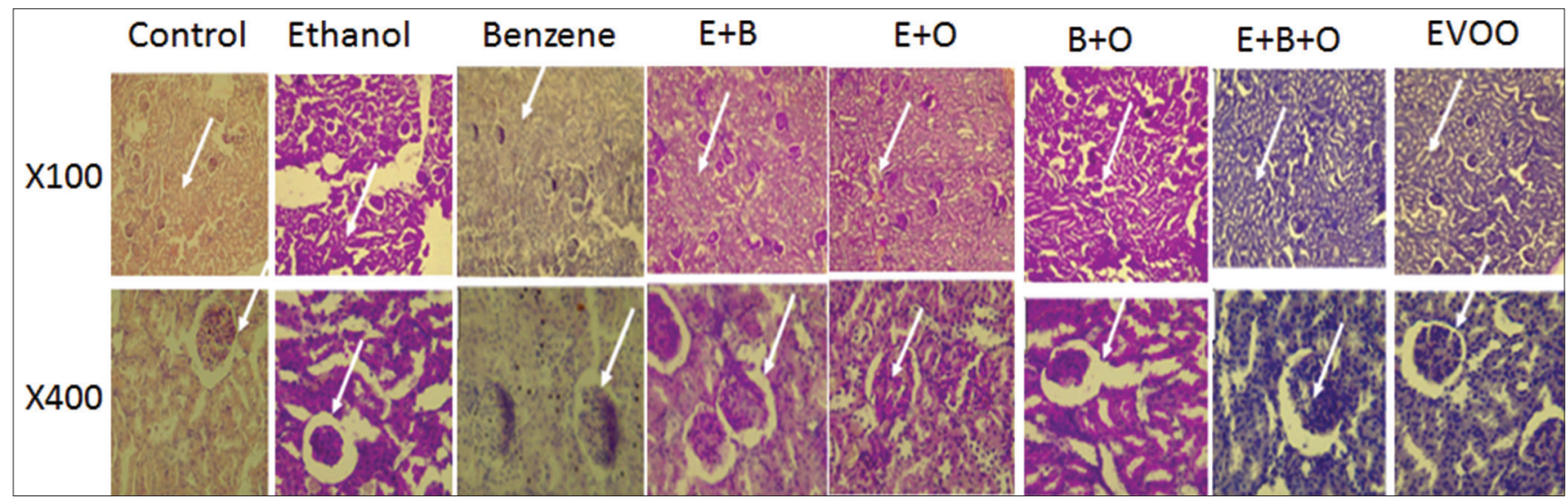

Fig. 6: Section showing renal tissue consisting of glomerulus, proximal tubule and distal tubule of control, ethanol, benzene, $E+B=E t h a n o l$ + Benzene, E+0=Ethanol + Extra Virgin Olive Oil, B+O=Benzene + Extra Virgin Olive Oil, E+B+0= Ethanol + Benzene + Extra Virgin Olive Oil, EVOO=Extra Virgin Olive Oil (PAS: $\times 100$ and $\times 400$ ) 
of $\mathrm{EVOO}$ in $\mathrm{E}+\mathrm{O}, \mathrm{B}+\mathrm{O}$, and $\mathrm{E}+\mathrm{B}+0$ groups just like the case in [15]. This explained the progresses in kidney disease with rises in Urea and Creatinine level of damaged kidney as claimed by the activities of benzene in [16].

\section{Histological results}

Hematoxylin and eosin (H\&E) (Fig. 5) stains showed Periodic AcidSchiff stain (PAS) (Fig. 6) showed Control group with normal renal tissue, Ethanol, Benzene and $\mathrm{E}+\mathrm{B}$ groups with remarkable fibrosis in all sections after inducing, $\mathrm{E}+\mathrm{O}, \mathrm{B}+\mathrm{O}$ and $\mathrm{E}+\mathrm{B}+\mathrm{O}$ without fibrosis as $\mathrm{EVOO}$ was administered to each group for treatment and EVOO group was without any evidence of fibrosis

\section{CONCLUSION}

Histological analysis of this study, therefore, reveals that EVOO indeed possesses anti-inflammatory potential.

\section{REFERENCES}

1. Linlin C, Huidan D, Hengmin C, Jing F, Zhicai Z, Junliang D, et al. Inflammatory responses and inflammation-associated diseases in organs. Oncotarget 2017;9:7204-18.

2. Takeuchi O, Akira S. Pattern recognition receptors and inflammation. Cell 2010;140:805-20.

3. Hörl WH. Nonsteroidal anti-inflammatory drugs and the kidney. Pharmaceuticals (Basel) 2010;3:2291-321

4. Neghab M, Hosseinzadeh K, Hassanzadeh J. Early liver and kidney dysfunction associated with occupational exposure to sub-threshold limit value levels of benzene, toluene, and xylenes in unleaded petrol Saf Health Work 2015;6:312-6.

5. Saeed A. Ethanol-induced hepatic and renal histopathological changes in BALB/c mice. J Natural Sci Res 2015;5:12-20.
6. Adebola AO, Adegoke AO, Toyin AI, Linda NN. Role of extra virgin olive oil on the liver of alcohol and benzene-treated Wistar rats. World J Med Sci 2021;18:51-8. Available from: https://www.idosi.org/ wjms/18(2)21/2.pdf

7. Ying $Z$, Yan $H$, Haihua $H$. Triptolide attenuates inflammatory response in membranous glomerulo-nephritis rat via downregulation of $\mathrm{NF}-\kappa \mathrm{B}$ signaling pathway. Kidney Blood Press Res 2016;41:901-10.

8. Suryanarayana V, Vulimiri, Mahedevan B, Reproductive Developmenta Toxicity of Solvents and Gases. $2^{\text {nd }}$ ed. Silo. Pub; 2017. p. 1409-46.

9. Abel EL, DiGiovanni J. The Molecular Basis of Cancer. $4^{\text {th }}$ ed., Vol. 7. Amsterdam, Netherlands: Elsevier; 2015. p. 103-28.

10. Das S, Vasudevan D. Alcohol induced effects on kidney. Indian J Clin Biochem 2008;23:4-9.

11. Tajmim A, Siddique AB, El Sayed K. Optimization of taste-masked (-)-oleocanthal effervescent formulation with potent breast cancer progression and recurrence suppressive activities. Pharmaceutics 2019;11:515.

12. Dhifi W, Khedher MB, Bellili S, Sadaka C, Wakim L, Beyrouthy ME, et al. Effects of olive drying and storage on the oxidative status, aroma chlorophyll and fatty acids composition of olive oil. Int J Pharm Pharm Sci 2015;7:102-8. Available from: https://www.innovareacademics.in/ journals/index.php/ijpps/article/view/1991

13. Giri D. Periodic Acid Schiff (PAS) Staining Technique for Carbohydrates; 2019. Available from: https://www.laboratoryinfo.com/ periodic-acid-schiff-pas-staining-technique-for-carbohydrates

14. Giri D. Hematoxylin and Eosin Staining: Principle, Procedure and Interpretation; 2019. Available from: https://www.laboratoryinfo.com/ hematoxylin-and-eosin-staining

15. Laaboudi W, Ghanam J, Ghoumari O, Sounni F, Merzouki M, Benlemlih M. Hypoglycemic and hypolipidemic effects of phenolic olive tree extract in streptozotocin diabetic rats. Int J Pharm Pharm Sci 2016;8:287-91.

16. Paidesetty SK, Rout SK, Sahoo J. Antimicrobial and antioxidant activities of some newly synthesized benzene-1, 3-diol congeners and their characterizatio. Int J Pharm Pharm Sci 2015;7:427-33. 